\title{
An Experimental Study on Effect of Replacing Natural Sand by Quarry Dust and Saw Dust on Properties of Concrete
}

\author{
K. Harish Kumar ${ }^{1}$, K. Chandra Venkata Shabarish ${ }^{2}$, G. Bhanu ${ }^{3}$, K. Durga Vara Prasad ${ }^{4}$, \\ Ch. Satish Kumar \\ ${ }^{1}$ Assistant Professor, Department of Civil Engineering, Lakireddy Bali Reddy College of Engineering, Mylavaram, \\ Andhra Pradesh, India, konaharishkumar@gmail.com \\ ${ }^{2,3,4,5}$ U. G Students, Department of Civil Engineering, Lakireddy Bali Reddy College of Engineering, Mylavaram,
}

\begin{abstract}
Construction industry is one of the contributing fator to the environmental crisis; the use of waste materials or industrial by-products from different industries as an alternative to conventional concrete materials would reduce this issue. The use of this material will contribute to sustainability in the building industry and protect natural resources. It can replace traditional concrete materials and use it. This study aims primarily to examine sand replacement to optimize the benefit of industrial by-products and other waste materials. Day by day, demand for sand is growing. Sand mining increases gradually as needed, with the impact from the mining of the river, water quality, and ecological effect generally affected. Therefore, it is very important to consider Sand Alternative in view of the need for sand in the future. Lack of sand affects construction work directly. The alternate material such as quarry dust and saw dust may be used in concrete to meet the need of fine aggregates. Quarry dust comes from the crushing of rocks, while sawdust refers to the fine size, powdery waste formed by sawing of wood. In this study, traditional mix 1:2.32:2.82 (M25) with water to binder ratio is maintained as 0.49 was used in this present study. Here the natural sand is replaced partly here by quarry dust (QD) and sawdust (SD) with different percentages i.e. is $50 \%$ of natural sand as constant and remaining $50 \%$ as the different proportions of Quarry dust and Saw dust. respectively by weight and effects of replacement on concrete is observed. The concrete was cast and their compressive, tensile strength and durability measured at 7, 14 and 28 days, respectively; the cubes of $150 \times 150 \times 150 \mathrm{~mm}$, and the cylinders of $15 \mathrm{~cm}$ of diameter and of $30 \mathrm{~cm}$ of height were cast. The incorporation of 0.5 percent glass fibers into concrete as a mixture will increase the compressive and the tensile strength of the concrete dramatically.
\end{abstract}

Key words: Quarry Dust (QD), Saw Dust (SD), Slump cone test, Compaction Factor test (CFT), Compressive Strength, tensile strength and Durability test.

\section{INTRODUCTION}

In construction sectors, cement, sand and aggregate are essential needs. Natural sand deposits like India are being exploited and serious threats to the environment and society are caused by developing countries like India (the Authors native country) that facing a lack of sufficient natural sand content [1]. The rapid sand extraction from the beds of the rivers causes problems because the river beds are deeper, vegetation is lost on the banks of river, the aquatic life is disturbed as well as agriculture also due the water table in the well has been lowered etc. Building industries in developing countries are therefore emphasizing the need for alternative materials to offset the natural sand market [2].

We can overcome this problem by using two methods (a) concrete is replaced by another material which is very difficult or impossible at present, in terms of workability, durability and strength (b) partly or entirely substituting specific raw materials. It is possible to have second alternative option. Now a day's lot of invention in the area of concrete technology are being carried out by different researchers [3]. We are attempting to solve this problem by substituting various residues for which we have published numerous papers suggesting various materials that can be used as a component substitute for raw materials such as cement, fine and coarse aggregates.

Sand is an important material used to prepare mortar and concrete and plays a major role in the construction of concrete mixes. The primary use of cement and mortar is generally high in use of natural sand [4]. Hence in developing countries, the demand for natural sand has been very high to meet rapid infrastructure growth. Fine aggregate physical and chemical properties influence the durability, workability and also strength of concrete, because fine aggregates are the key components of concrete and cement mortar. Fine and gross aggregates together make up 75-80 percent of all concrete volume [5], so it is very important that the correct form of concrete and a good quality aggregate should be select from 
K. Harish Kumar et al., International Journal of Emerging Trends in Engineering Research, 8(5), May 2020, 1906 - 1915

site. Natural sand recently became a very expensive material because of the need for cheap and easily accessible alternative materials in the building industry. Alternative materials have already been used to substitute natural sand, such as fly-ash, quarry dust or limestone powder, filtered sand, copper slag etc [6]. as partly or entirely replacement of natural sand in concrete and mortar combinations. Other suitable materials such as crushed stone dust, quarry dust, glass powder, recycled concrete etc. have been partially or completely substituted for natural sand, with a view of preserving ecological balance in the last two decades [7]. Because of the above facts, it is therefore important to try viable alternatives to natural sand.

\subsection{Objectives}

The main focus of this study, is the behaviour of concrete that partially replaces sand with QD and SD. In order to assess the possibility of its use, tests on workability, strength and durability must be performed. The w/c ratio maintains as 0.49 in all proportions and sands are replaced by QD and SD, as shown in Table 1.

Table 1: Fine Aggregate Replacement levels

\begin{tabular}{|l|l|l|l|}
\hline Specimens & $\begin{array}{l}\text { Natural } \\
\text { Sand }\end{array}$ & QD & SD \\
\hline $\mathrm{S}_{1}$ & $100 \%$ & - & - \\
\hline $\mathrm{S}_{2}$ & $50 \%$ & $45 \%$ & $5 \%$ \\
\hline $\mathrm{S}_{3}$ & $50 \%$ & $40 \%$ & $10 \%$ \\
\hline $\mathrm{S}_{4}$ & $50 \%$ & $35 \%$ & $15 \%$ \\
\hline $\mathrm{S}_{5}$ & $50 \%$ & $30 \%$ & $20 \%$ \\
\hline $\mathrm{S}_{6}$ & $50 \%$ & $25 \%$ & $25 \%$ \\
\hline
\end{tabular}

\section{METHODOLOGY}

This study focus on the properties, compressive strength, tensile strength and durability tests of sand alternatives i.e. QD and SD. Concrete mix design with a different \% of quarry dust and saw dust have been made. The slump test and compaction factor test led to the measurement of the workability of the mix design [8]. They were cured in underwater for a specified period of 7, 14 and 28 days after preparation of the concrete samples. Compressive and tensile strength tests were carried out to determine concrete strength and comparative analysis were made with ordinary concrete.

\section{MATERIALS AND MIX DESIGN}

The Successive phases of the preliminary study were programmed and represented in Figure 1.

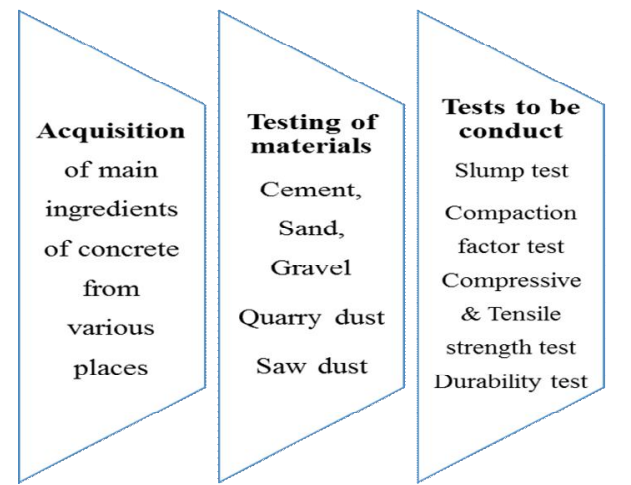

Figure 1: Successive phases of preliminary study

For the adoption of ordinary concrete constituents, the concrete mix design of the M25 was developed using IS 10262- 2009 method [9]. The alternative materials with a different natural sand percentage, i.e. 50 percent of natural sand, are as constant in the present research sequence and 50 percent as the different quarry dust and saw dust proportions. Various specimens were cast and examined in order to study concrete characteristics [10]. The water cement ratio of 0.49 is maintained during the investigation process.

3.1 Cement: - According to Indian standards, KPC Cement (OPC) of 53 grade was locally available [11]. Various tests were performed according to IS 8112- 1989. It was determined in Figure 2.

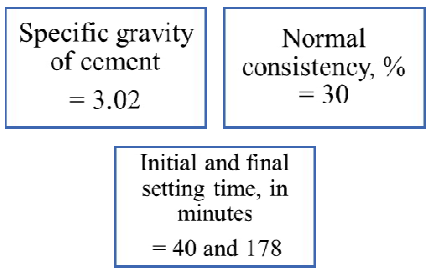

Figure 2: Tests on Cement

3.2 Fine Aggregate: - According to Table IS 383- 1970 the sand available on site was obtained and conformed to zoneIII. Several tests were performed according to IS 383(1970) procedure and tabulated in Table 2.

Table 2: Tests on Fine Aggregate

\begin{tabular}{|c|l|c|c|c|}
\hline S No & \multicolumn{1}{|c|}{ Properties } & Sand & QD & SD \\
\hline 1 & Sieve Analysis & \multicolumn{3}{|c|}{ Zone-III } \\
\hline 2 & Void ratio & 3.14 & 3.14 & 2.48 \\
\hline 3 & Specific gravity & 2.62 & 2.75 & 1.15 \\
\hline 4 & Water absorption & 1.5 & 1.5 & 2 \\
\hline 5 & Bulk density, Kg/m & 1450 & 1760 & 221 \\
\hline 6 & Silt content & 3.61 & 3.41 & 3.03 \\
\hline 7 & Bulking of aggregate & $30 \%$ & $30 \%$ & $80 \%$ \\
\hline
\end{tabular}

\subsection{Alternative materials to Sand}

Some of the alternative materials such as quarry and saw dust are used to replace the natural sand. 
(a) Quarry Dust (QD): - The quarry dust is produced by crushers in quarrying operations. The dust was collected in neighboring quarries of Mylavaram. The main goal of the present study is to investigate the effect of quarry dust in partial replacement of sand in concrete [12]. Several tests were performed according to IS 383(1970) procedure [13] and tabulated in Table 2.

(b) Saw Dust (SD): - Sawdust is obtained from wood. The saw dust is made of chips from various hardwoods. It was sundried and kept in waterproof bags. For replacement the sawdust is sieved through $1.18 \mathrm{~mm}$. Several tests were performed according to IS 383(1970) procedure [13] and tabulated in Table 2.

3.4 Coarse Aggregate (Granite): - A crushed stone aggregates were obtained from the lab which confirms IS 383-1970 [13]. This has been tested on various properties, shown in Figure 3.

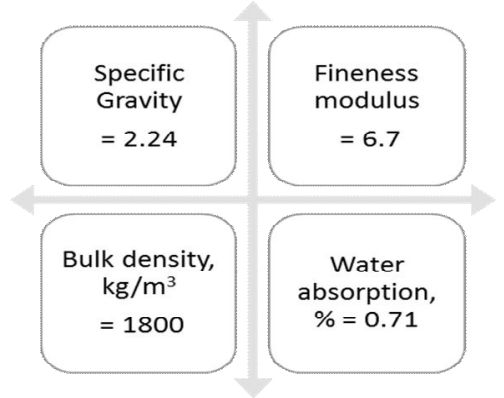

Figure 3: Tests on Coarse Aggregate

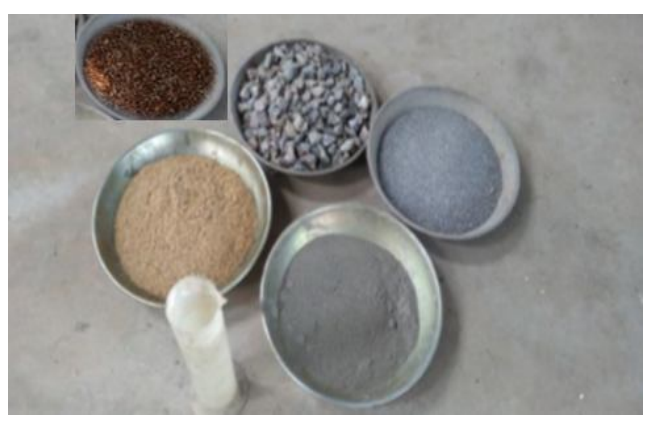

Figure 4: Materials of Concrete

3.5 Admixture (GF): - In this study the glass fibers are alkaline resistant (AR), $6 \mathrm{~mm}$ long, 428 aspect ratio, with a 73 GPa elastic modulus shown in Fig.2. Using these fibers in concrete would greatly increase the compressive and tensile strength of the concrete significantly [14]. Tests were performed in this study for concrete with 0.5 percent of glass fiber in cement by adding each specimen as an admixture.

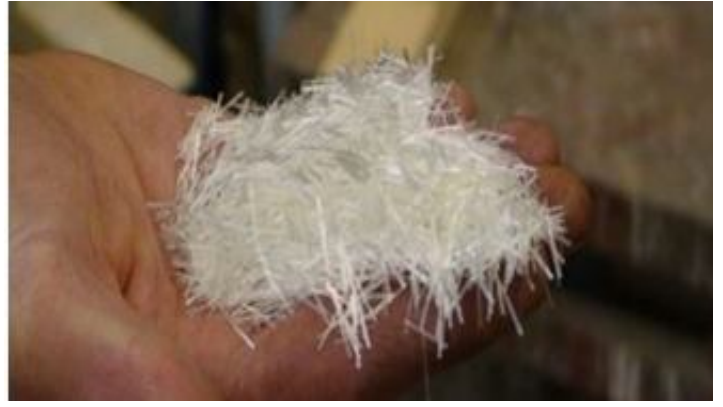

Figure 5: Glass Fibers (GF)

\subsection{Concrete Mix Design}

In accordance with IS 10262:2009 and IS 456:2000, the mix proportioning has been performed [15]. For M25-grade concrete, the target value was $31.6 \mathrm{~N} / \mathrm{mm}^{2}$. The ratio of the $\mathrm{w}$ / c was 0.49. The mix proportion ratio is 1:1.38:2.97 i.e. cement: fine aggregate: coarse aggregate, which was mixed correctly.

The specimens were cast and tested to study the use of QD and $\mathrm{SD}$ in concrete as a replacement for sand. The mixture with different percentages of quarry dust and saw dust replacement in fine aggregate in analyzed. $150 \mathrm{~mm} \times 150 \mathrm{~mm} \times 150 \mathrm{~mm}$ cubes and cylinder of standard size, $150 \mathrm{~mm}$ diameter and $300 \mathrm{~mm}$ height were used to check the compressive and tensile strength. They were immersed in water for 24 hours and the air cooled in the laboratory. Six types of concretes were produced and tested at age 7, 14 and 28 days. Hence, total of 108 cubes and 36 cylinders were produced for the tests. The quantity of constituent materials is shown in Table 3.

Table 3: Quantity of constituent materials

\begin{tabular}{|c|c|c|c|c|c|c|}
\hline \multirow{2}{*}{ Mix No. } & \multicolumn{6}{|c|}{ Content kg/m } \\
\cline { 2 - 7 } & OPC & F. A & QD & SD & C.A & Water \\
\hline$S_{1}$ & 402.7 & 555.30 & - & - & 1194 & 197.4 \\
\hline$S_{2}$ & 402.7 & 277.65 & 249.88 & 27.77 & 1194 & 197.4 \\
\hline$S_{3}$ & 402.7 & 277.65 & 222.12 & 55.53 & 1194 & 197.4 \\
\hline$S_{4}$ & 402.7 & 277.65 & 194.35 & 83.29 & 1194 & 197.4 \\
\hline$S_{5}$ & 402.7 & 277.65 & 166.59 & 111.06 & 1194 & 197.4 \\
\hline$S_{6}$ & 402.7 & 277.65 & 138.83 & 138.83 & 1194 & 197.4 \\
\hline
\end{tabular}

\subsection{Laboratory Test}

A series of investigations have been done out in relation to the performance of concrete using alternative sand materials, i.e. quarry dust and sawdust as fine aggregate separately [16]. A sequence of laboratory tests performed which includes sieve analysis, slump cone test, Compaction factor, trial mix, compressive \& tensile strength tests, and durability tests as shown in Figure 6. 
K. Harish Kumar et al., International Journal of Emerging Trends in Engineering Research, 8(5), May 2020, 1906 - 1915

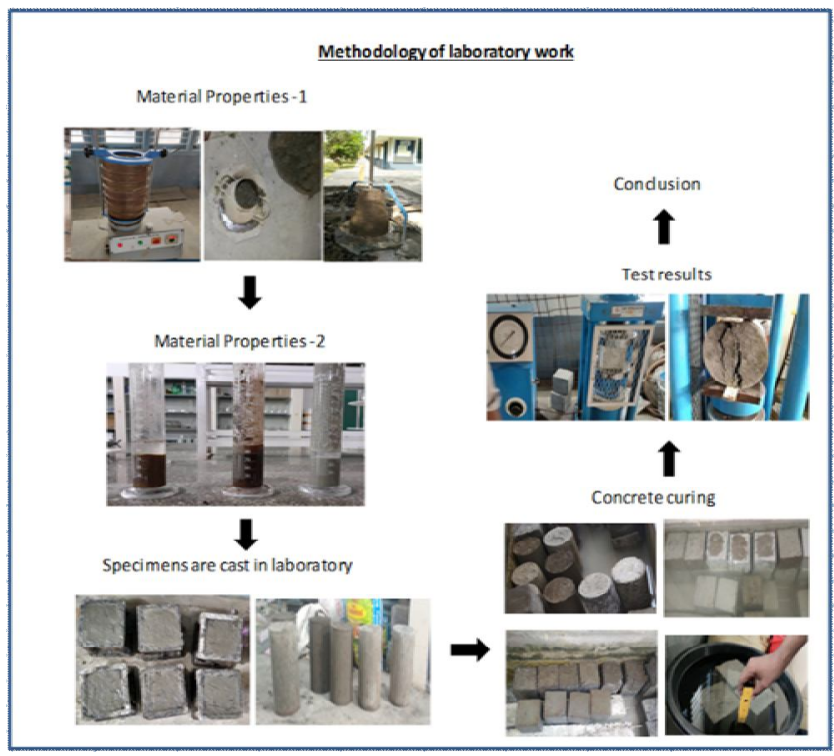

Figure 6: Sequence of laboratory work

\section{RESULTS AND ANALYSIS}

\subsection{Slump Cone Test:}

Slump cone test is performed to check the consistency of concrete. The height of the slump is $30 \mathrm{~cm}$. The slumps for the different concretes of $\mathrm{QD}$ and $\mathrm{SD}\left(\mathrm{S}_{1}\right.$ to $\left.\mathrm{S}_{4}\right)$ replacement ranged from $6.0 \mathrm{~cm}$ to $10.0 \mathrm{~cm}$, according to Table 4 . The specimens $S_{5} \& S_{6}$ slumps can be classified as low workability because as \% of saw dust increases the slump values decreases. $S_{2}$ concrete specimen can be classified as medium workability. From the results, [17] greater replacement in percentage of QD \& SD decreases concrete's workability as shown in Figure 7 of slump values with varying $\%$ of concrete.

Table 4: Slump values for varying $\%$ of concrete samples

\begin{tabular}{|c|c|c|c|c|c|c|}
\hline Specimen & FA & QD & SD & \multicolumn{3}{|c|}{ SLUMP (cm) } \\
\hline & & & & 1 & 2 & Avg. \\
\hline $\mathrm{S}_{1}$ & $100 \%$ & $0 \%$ & $0 \%$ & 05 & 07 & 06 \\
\hline $\mathrm{S}_{2}$ & $50 \%$ & $45 \%$ & $5 \%$ & 09 & 07 & 08 \\
\hline $\mathrm{S}_{3}$ & $50 \%$ & $40 \%$ & $10 \%$ & 12 & 08 & 10 \\
\hline $\mathrm{S}_{4}$ & $50 \%$ & $35 \%$ & $15 \%$ & 06 & 08 & 07 \\
\hline $\mathrm{S}_{5}$ & $50 \%$ & $30 \%$ & $20 \%$ & 07 & 06 & 6.5 \\
\hline $\mathrm{S}_{6}$ & $50 \%$ & $25 \%$ & $25 \%$ & 04 & 06 & 05 \\
\hline
\end{tabular}

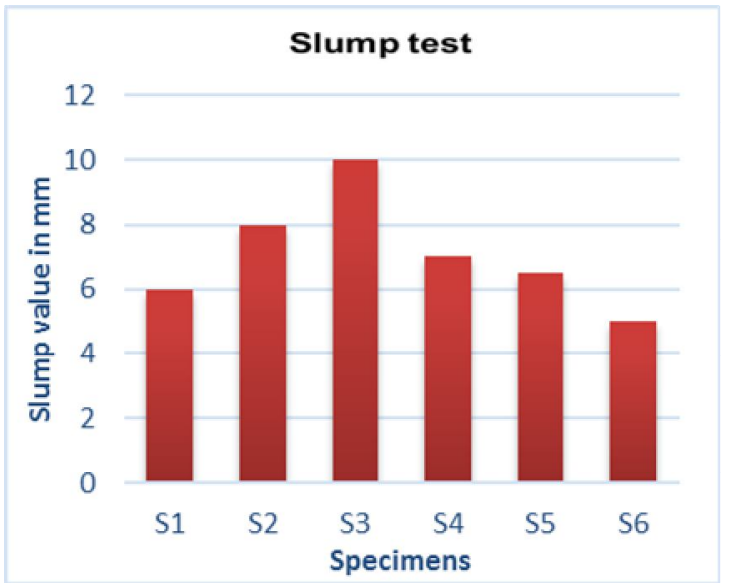

Figure 7: Slump values for varying $\%$ of concrete samples

\subsection{Compaction Factor Test (CFT)}

The compaction factor of six different types of concrete ranged from 0.73-0.94 as shown in Table 5. The normal range of compaction factor is between 0.8 to 0.92 [18]. This technique is best suited for dry mixes that are not appropriate for slump tests. This test is currently widely replaced by the slump test to control the workability of concrete. From the results, the compacting factor values are approximately taken as medium workability according to Figure 8 .

Table 5: CFT values for varying \% of concrete samples

\begin{tabular}{|c|c|c|c|c|}
\hline Specimen & FA & QD & SD & $\begin{array}{c}\text { COMACTION } \\
\text { FACTOR }\end{array}$ \\
\hline $\mathrm{S}_{1}$ & $100 \%$ & $0 \%$ & $0 \%$ & 0.93 \\
\hline $\mathrm{S}_{2}$ & $50 \%$ & $45 \%$ & $5 \%$ & 0.94 \\
\hline $\mathrm{S}_{3}$ & $50 \%$ & $40 \%$ & $10 \%$ & 0.81 \\
\hline $\mathrm{S}_{4}$ & $50 \%$ & $35 \%$ & $15 \%$ & 0.73 \\
\hline $\mathrm{S}_{5}$ & $50 \%$ & $30 \%$ & $20 \%$ & 0.81 \\
\hline $\mathrm{S}_{6}$ & $50 \%$ & $25 \%$ & $25 \%$ & 0.73 \\
\hline
\end{tabular}

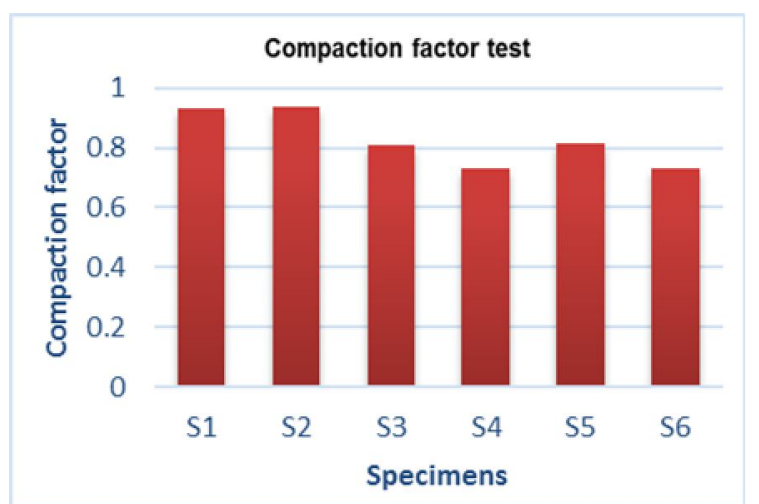

Figure 8: CFT for varying $\%$ of concrete samples 


\subsection{Compressive Strength Test}

Compressive strength is the primary physical property of concrete and the one most used in design [19]. The compressive strength is measured by force units by cross-section area (N/Sqmm or MPa) as shown in Figure 11. The compressive strength equation is

$$
\mathbf{F}_{\mathrm{C}}=\mathbf{P} / \mathbf{A}
$$

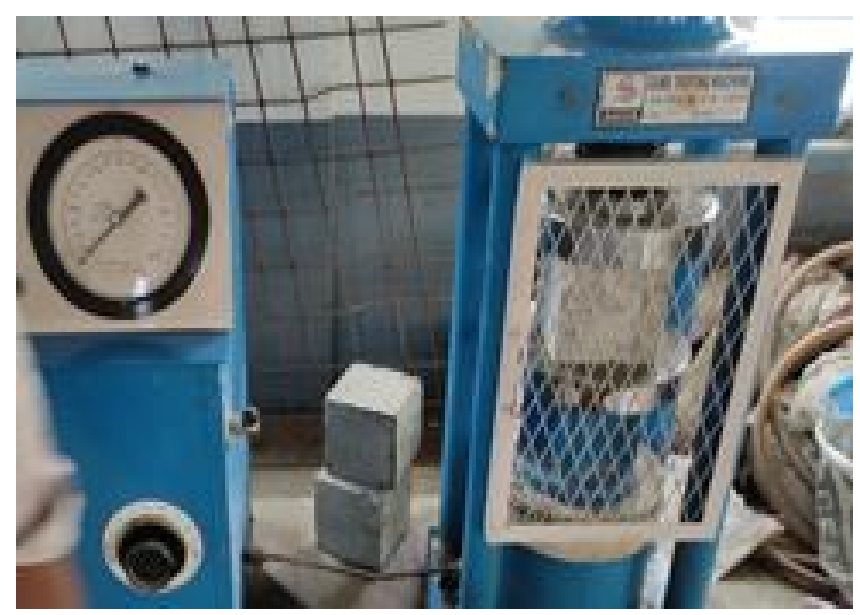

Figure 9: Testing on Compression testing machine

From the Figure 10, it concluded that the compressive strength of the concrete mix decreases as replacement of quarry and saw dust in sand increases [20].

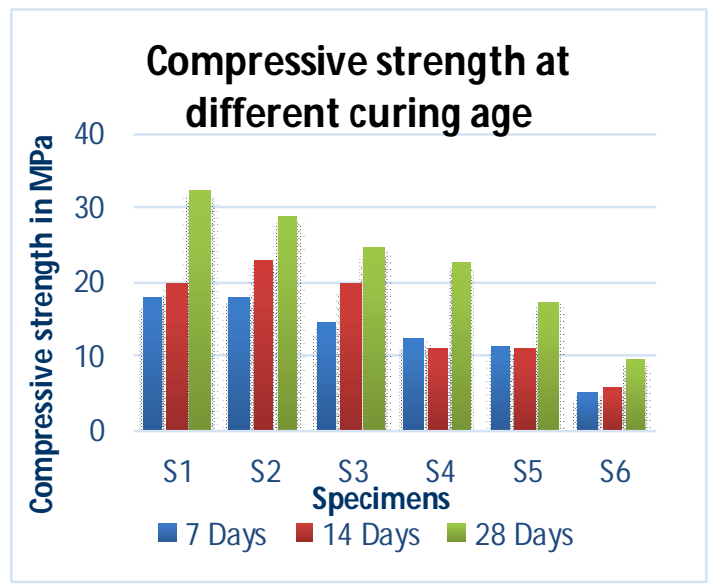

Figure 10: Compressive strength at different curing age

\subsection{Split Tensile Strength Test}

Tensile concrete strength (tensile stress) is the capacity of the concrete to withstand the friction force without breaking as shown in Figure 11. As per IS 456:2000 the tensile strength of concrete [21] given by the equation.

$$
f_{c r}=0.7 \sqrt{f_{c k}} \text { in } \mathrm{N} / \mathrm{mm}^{2}
$$

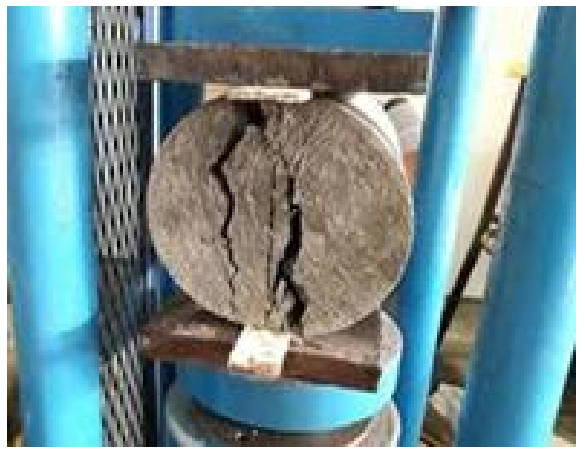

Figure 11: Tensile test

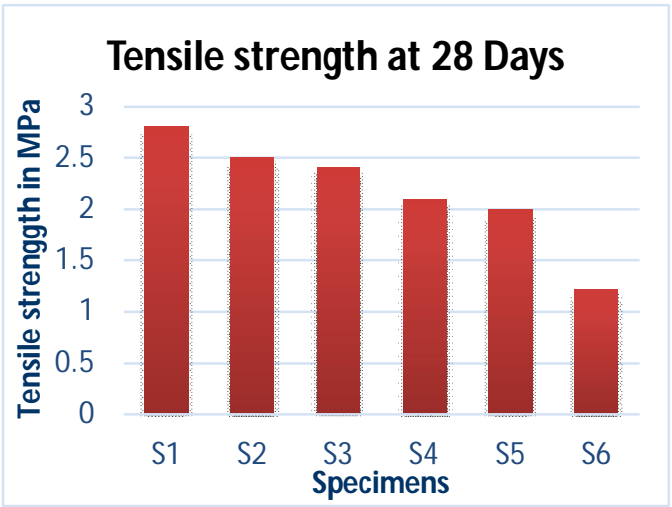

Figure 12: Tensile strength at 28 days

From the Figure 12, it concluded that the tensile strength of the concrete mix decreases as replacement of quarry and saw dust in sand increases.

\subsection{Durability Tests}

\subsubsection{Study on Chloride attack}

Nacl solution is prepared and mixed with distilled water by weight of $5 \%$ of sodium chloride. The cubes were immersed in the solution for 28 days and were removed \& dried up on the concrete as shown in Figure 13. The cube surface of the specimen was cleaned [22] and dry weights calculated. After 28 days the weight loss and strength reduction ratio was found and tabulated in Table 6 and Table 7.

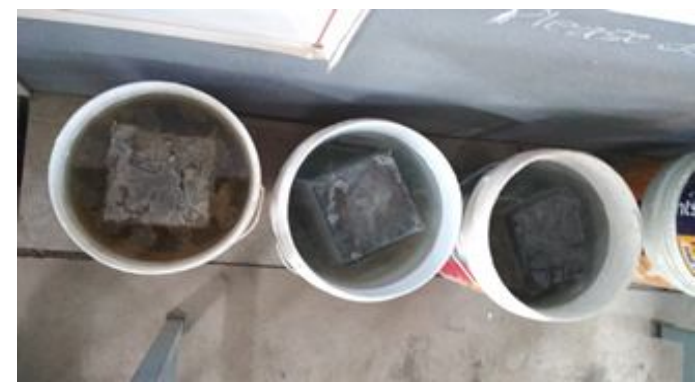

Figure 13: Cubes in Nacl solution 
K. Harish Kumar et al., International Journal of Emerging Trends in Engineering Research, 8(5), May 2020, 1906 - 1915

Table 6: \% of cubes weight loss in Nacl solution

\begin{tabular}{|c|c|c|c|}
\hline Specimen & $\begin{array}{l}\text { Weight of } \\
\text { cube before } \\
\text { immersion } \\
\text { in Kg }\end{array}$ & $\begin{array}{l}\text { Weight of } \\
\text { cube after } \\
\text { immersion } \\
\text { in Kg }\end{array}$ & $\begin{array}{l}\text { Reduction } \\
\text { in weight } \\
\text { \% }\end{array}$ \\
\hline $\mathrm{S}_{1}$ & 8.9 & 8.690 & 2.42 \\
\hline $\mathrm{S}_{2}$ & 8.610 & 8.400 & 2.5 \\
\hline $\mathrm{S}_{3}$ & 8.190 & 7.970 & 2.76 \\
\hline $\mathrm{S}_{4}$ & 7.980 & 7.750 & 2.96 \\
\hline $\mathrm{S}_{5}$ & 7.770 & 7.530 & 3.19 \\
\hline $\mathrm{S}_{6}$ & 7.65 & 7.410 & 3.24 \\
\hline
\end{tabular}

Table 7: \% of cubes strength reduction in Nacl solution

\begin{tabular}{|l|l|l|l|}
\hline Specimen & $\begin{array}{l}\text { Compressive } \\
\text { strength } \\
\text { before } \\
\text { immersion, } \\
\mathbf{N}_{\mathbf{m m}^{2}}\end{array}$ & $\begin{array}{l}\text { Compressive } \\
\text { strength } \\
\text { after } \\
\text { immersion, } \\
\mathbf{N}_{\mathbf{m m}^{2}}\end{array}$ & $\begin{array}{l}\text { Reduction in } \\
\text { Compressive } \\
\text { strength \% }\end{array}$ \\
\hline $\mathrm{S}_{1}$ & 32.38 & 19.84 & 38.73 \\
\hline $\mathrm{S}_{2}$ & 28.93 & 20.32 & 29.76 \\
\hline $\mathrm{S}_{3}$ & 24.61 & 16.93 & 31.21 \\
\hline $\mathrm{S}_{4}$ & 22.57 & 8.73 & 61.32 \\
\hline $\mathrm{S}_{5}$ & 17.29 & 1.30 & 92.1 \\
\hline $\mathrm{S}_{6}$ & 9.44 & 0.5 & 94 \\
\hline
\end{tabular}

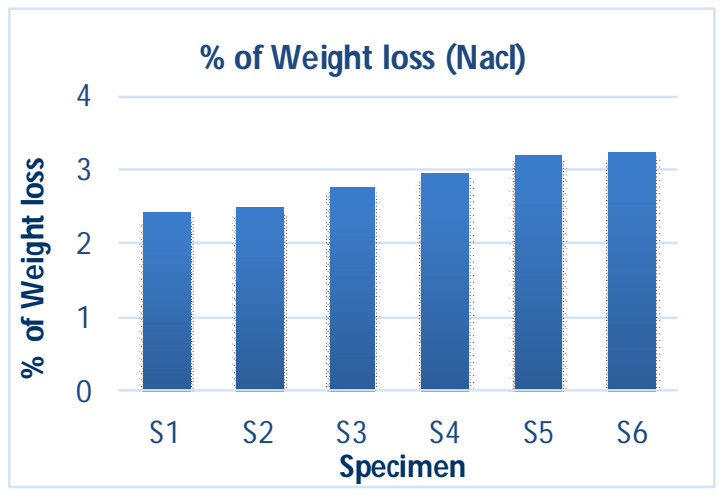

Figure 14: \% of weight loss (Nacl)

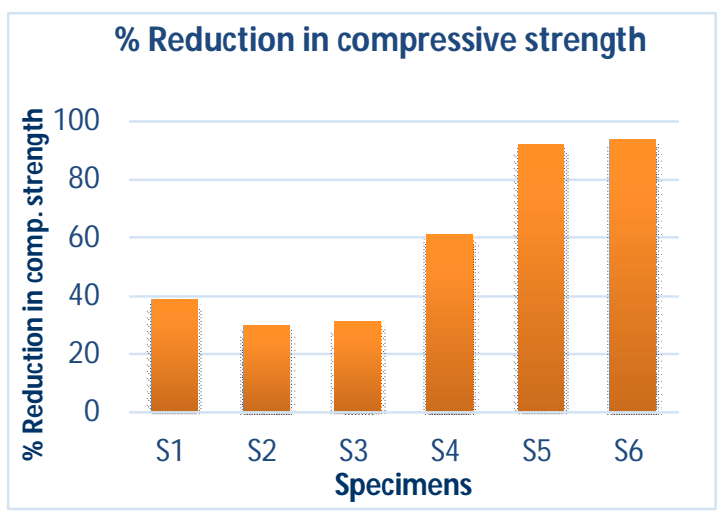

Figure 15: \% reduction in compressive strength

An acid attack affects any concrete specimen [23]. For samples $\mathrm{S}_{6}$, the outside portion of the cubes is bust where as $\mathrm{S}_{2}$ specimen gets exposed to greater acid resistance than control specimen $S_{1}$. It was found that the \% of weight loss for controlled concrete was 2.42 percent based on the test results. The extreme \% of weight loss is $\mathrm{S}_{6}$ concrete specimen 3.24 as shown in Figure 14. The reduction in compressive strength for controlled concrete is $38.73 \%$. Greater reduction in compressive strength is found at $\mathrm{S}_{6}$ specimen $94 \%$ as shown in Figure 15.

\subsubsection{Study on Sulphate attack}

$\mathrm{MgSO}_{4}$ solution is prepared and mixed with distilled water by weight of 5\% of magnesium sulphate. The cubes were immersed in the solution for 28 days and were removed \& dried up on the concrete as shown in Figure 16.

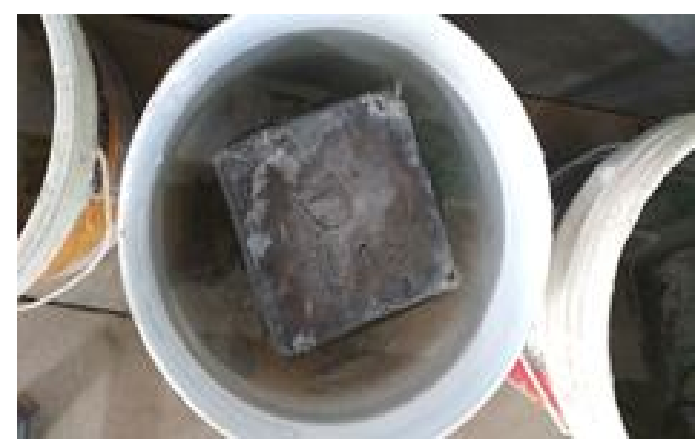

Figure 16: Cubes in $\mathrm{MgSO}_{4}$ solution

The cube surface of the specimen was cleaned and dry weights calculated. After 28 days the weight loss \& strength reduction ratio was found and tabulated in Table 8 and Table 9 . 
K. Harish Kumar et al., International Journal of Emerging Trends in Engineering Research, 8(5), May 2020, 1906 - 1915

Table 8: $\%$ of cubes weight loss in $\mathrm{MgSO}_{4}$ solution

\begin{tabular}{|c|c|c|c|}
\hline Specimen & $\begin{array}{c}\text { Weight of } \\
\text { cube before } \\
\text { immersion in } \\
\text { Kg }\end{array}$ & $\begin{array}{c}\text { Weight of } \\
\text { cube after } \\
\text { immersion } \\
\text { in Kg }\end{array}$ & $\begin{array}{c}\text { Reduction in } \\
\text { weight \% }\end{array}$ \\
\hline $\mathrm{S}_{1}$ & 8.650 & 8.520 & 1.53 \\
\hline $\mathrm{S}_{2}$ & 8.630 & 8.490 & 1.65 \\
\hline $\mathrm{S}_{3}$ & 8.290 & 8.140 & 1.84 \\
\hline $\mathrm{S}_{4}$ & 7.880 & 7.690 & 2.47 \\
\hline $\mathrm{S}_{5}$ & 7.880 & 7.680 & 2.6 \\
\hline $\mathrm{S}_{6}$ & 7.170 & 7.070 & 1.41 \\
\hline
\end{tabular}

Table 9: $\%$ of cubes strength reduction in $\mathrm{MgSO}_{4}$ solution

\begin{tabular}{|c|c|c|c|}
\hline $\begin{array}{c}\text { Specime } \\
\mathbf{n}\end{array}$ & $\begin{array}{c}\text { Compressiv } \\
\text { e strength } \\
\text { before } \\
\text { immersion, } \\
\mathbf{N} / \mathbf{m m}\end{array}$ & $\begin{array}{c}\text { Compressiv } \\
\text { e strength } \\
\text { after } \\
\text { immersion, } \\
\mathbf{N} / \mathbf{m m}\end{array}$ & $\begin{array}{c}\text { Reduction in } \\
\text { Compressiv } \\
\text { e strength } \\
\%\end{array}$ \\
\hline $\mathrm{S}_{1}$ & 32.38 & 21.03 & 35.05 \\
\hline $\mathrm{S}_{2}$ & 28.93 & 21 & 27.65 \\
\hline $\mathrm{S}_{3}$ & 24.61 & 20.18 & 18.00 \\
\hline $\mathrm{S}_{4}$ & 22.57 & 15.84 & 29.8 \\
\hline $\mathrm{S}_{5}$ & 17.29 & 1.46 & 91.5 \\
\hline $\mathrm{S}_{6}$ & 9.44 & 0.42 & 95.5 \\
\hline
\end{tabular}

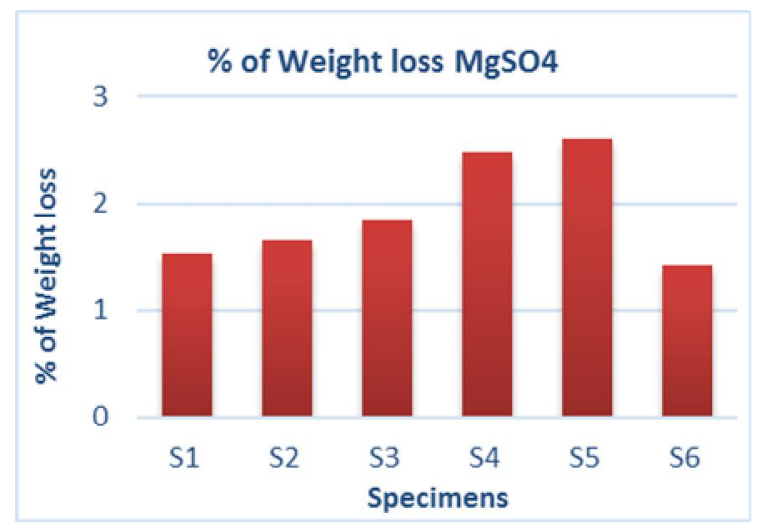

Figure 17: \% of weight loss $\left(\mathrm{MgSO}_{4}\right)$

An acid attack affects any concrete specimen [23]. For samples $S_{6}$, the outside portion of the cubes is bust where as $S_{3}$ specimen gets exposed to greater acid resistance than control specimen $\mathrm{S}_{1}$. It was found that the $\%$ of weight loss for controlled concrete was 1.53 percent based on the test results. The extreme $\%$ of weight loss is $\mathrm{S}_{5}$ concrete specimen as shown in Figure 17.

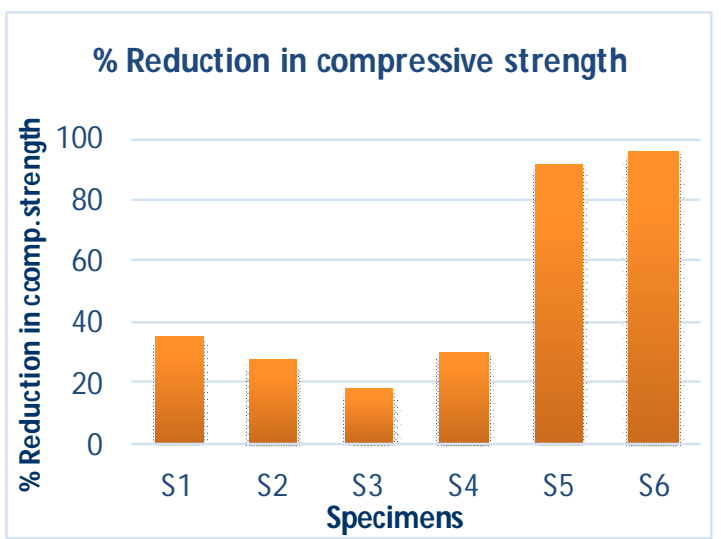

Figure 18: $\%$ of reduction in compressive strength $\left(\mathrm{MgSO}_{4}\right)$

The reduction in compressive strength for controlled concrete is $35.05 \%$. Greater reduction in compressive strength is found at $\mathrm{S}_{6}$ specimen $95.50 \%$ as shown in Figure 18.

\subsubsection{Study on Hydrochloric acid attack}

HCL solution is prepared and mixed with distilled water by weight of $5 \%$ of hydrochloric acid. The cubes were immersed in the solution for 28 days and were removed $\&$ dried up on the concrete as shown in Figure 19. The cube surface of the specimen was cleaned and dry weights calculated. After 28 days the weight loss and strength reduction ratio was found and tabulated in Table 10 and Table 11.

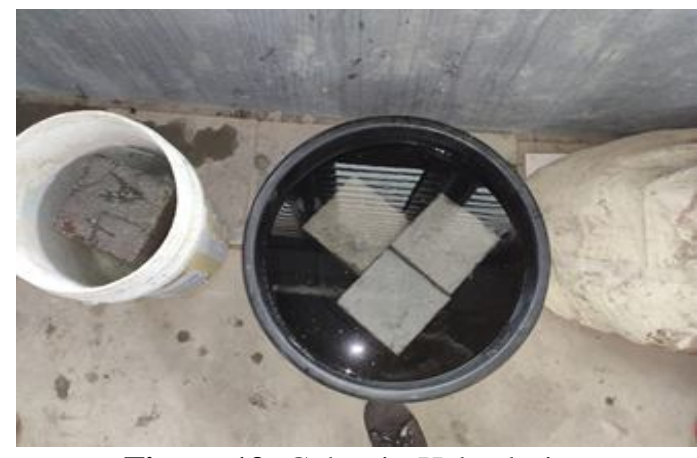

Figure 19: Cubes in Hcl solution

Table 10: $\%$ of cubes weight loss in Hcl solution

\begin{tabular}{|l|l|l|l|}
\hline $\begin{array}{l}\text { Specime } \\
n\end{array}$ & $\begin{array}{l}\text { Weight of } \\
\text { cube before } \\
\text { immersion } \\
\text { in Kg }\end{array}$ & $\begin{array}{l}\text { Weight of } \\
\text { cube after } \\
\text { immersion } \\
\text { in Kg }\end{array}$ & $\begin{array}{l}\text { Reduction weight } \\
\text { in wo } \\
\text { \% }\end{array}$ \\
\hline$S_{1}$ & 8.950 & 8.86 & 1.01 \\
\hline$S_{2}$ & 8.370 & 8.25 & 1.45 \\
\hline$S_{3}$ & 8.22 & 8.12 & 1.23 \\
\hline$S_{4}$ & 7.48 & 7.34 & 0.93 \\
\hline$S_{5}$ & 7.59 & 7.53 & 0.79 \\
\hline$S_{6}$ & 7.41 & 7.30 & 1.5 \\
\hline
\end{tabular}


K. Harish Kumar et al., International Journal of Emerging Trends in Engineering Research, 8(5), May 2020, 1906 - 1915

Table 11: \% of cubes strength reduction in Hcl solution

\begin{tabular}{|c|c|c|c|}
\hline $\begin{array}{c}\text { Specime } \\
\mathbf{n}\end{array}$ & $\begin{array}{c}\text { Compressiv } \\
\text { e strength } \\
\text { before } \\
\text { immersion, } \\
\mathbf{N} / \mathbf{m m}\end{array}$ & $\begin{array}{c}\text { Compressiv } \\
\text { e strength } \\
\text { after } \\
\text { immersion, } \\
\mathbf{N} / \mathbf{m m}\end{array}$ & $\begin{array}{c}\text { Reduction in } \\
\text { Compressiv } \\
\text { e strength } \\
\%\end{array}$ \\
\hline $\mathrm{S}_{1}$ & 32.38 & 16.92 & 47.74 \\
\hline $\mathrm{S}_{2}$ & 28.93 & 17.11 & 41.93 \\
\hline $\mathrm{S}_{3}$ & 24.61 & 16.8 & 30.47 \\
\hline $\mathrm{S}_{4}$ & 22.57 & 10.4 & 53.92 \\
\hline $\mathrm{S}_{5}$ & 17.29 & 8 & 53.73 \\
\hline $\mathrm{S}_{6}$ & 9.44 & 0.54 & 94.3 \\
\hline
\end{tabular}

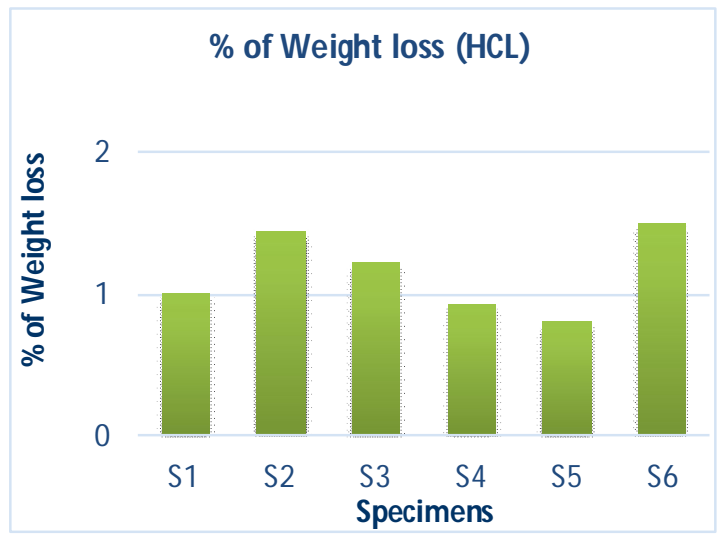

Figure 20: \% of weight loss $(\mathrm{Hcl})$

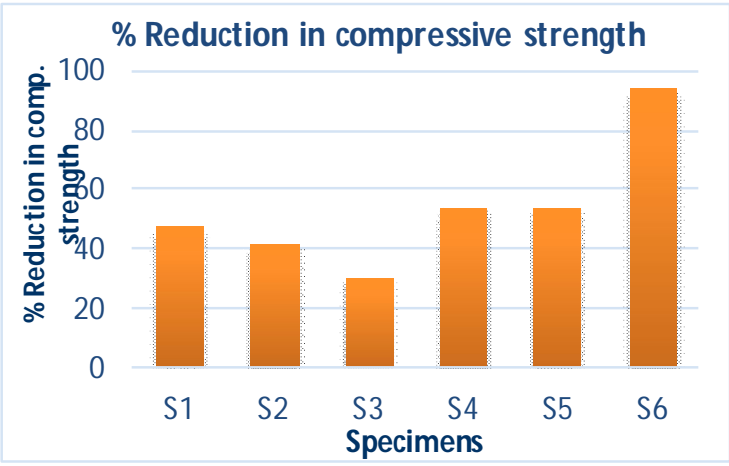

Figure 21: \% of reduction in compressive strength $(\mathrm{Hcl})$

An acid attack affects any concrete specimen [23]. For samples $\mathrm{S}_{6}$, the outside portion of the cubes is bust where as $\mathrm{S}_{2}$ specimen gets exposed to greater acid resistance than control specimen $\mathrm{S}_{1}$. It was found that the $\%$ of weight loss for controlled concrete was 1.01 percent based on the test results. The extreme $\%$ of weight loss is $\mathrm{S}_{6}$ concrete specimen as shown in Figure 20. The reduction in compressive strength for controlled concrete is $47.74 \%$. Greater reduction in compressive strength is found at $S_{6}$ specimen $94.3 \%$ as shown in Figure 21.

\section{COMPARATIVE STUDY}

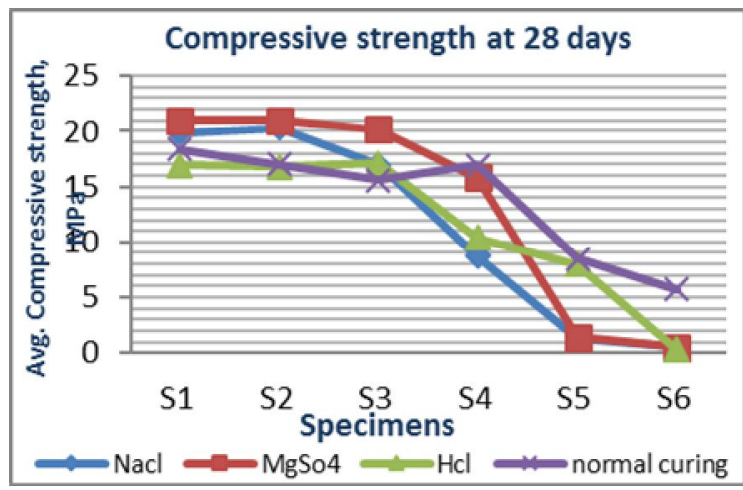

Figure 22: Compressive strength 28 days at different curing conditions

From the Figure 22, $S_{2} \& S_{3}$ specimen shows better strength compared to control concrete $S_{1}$.

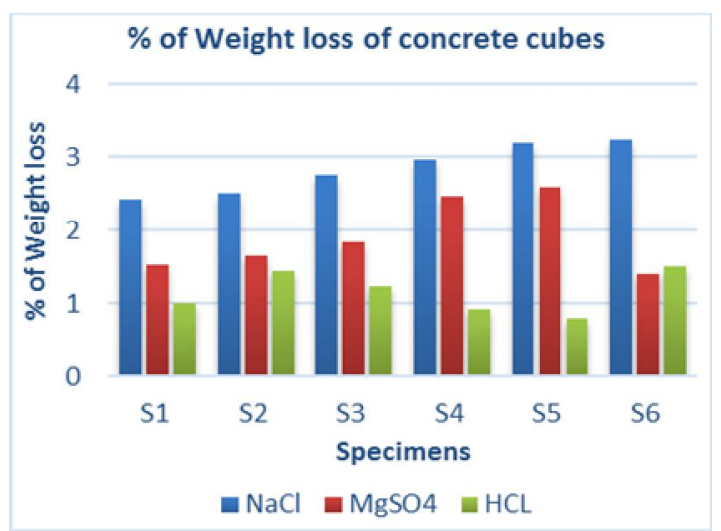

Figure 23: $\%$ of weight loss of concrete cubes

Figure 23, displays the $\%$ of weight loss of concrete cubes immersed in different solutions. From this one well-known that maximum percentage of weight loss discovered at $\mathrm{S}_{6}$ specimen.

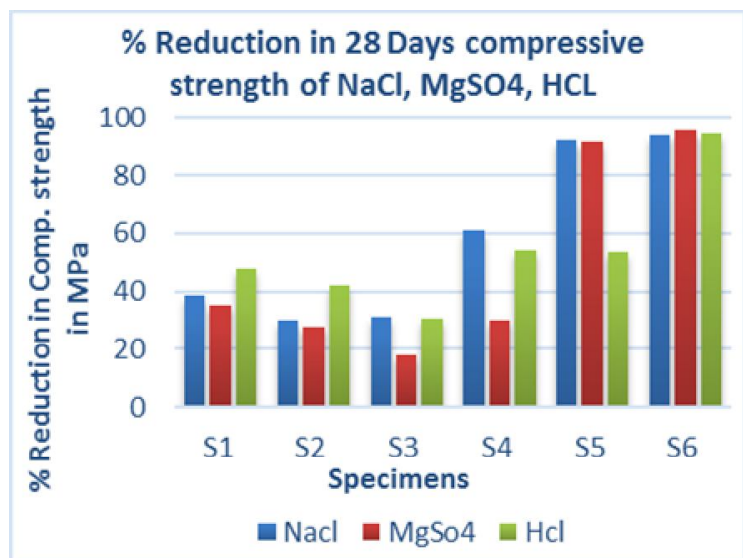

Figure 24: $\%$ reduction in 28 days' compressive strength of $\mathrm{Nacl}, \mathrm{MgSO}_{4}, \mathrm{Hcl}$

In Figure 24 the \% reduction in compressive strength with various percentages of Quarry Dust and Saw Dust was shown. 
K. Harish Kumar et al., International Journal of Emerging Trends in Engineering Research, 8(5), May 2020, 1906 - 1915

The highest $\%$ of loss in compressive strength is found at $\mathrm{S}_{6}$ specimen where as $S_{2} \& S_{3}$ show greater acid resistance compared to control specimen $S_{1}$.

\section{CONCLUSIONS}

- Greater replacement in percentage by QD \& SD decreases concrete's workability. But upto $\mathrm{S}_{4}$ specimen it shows medium workability.

- The highest $\%$ of reduction in Compressive Strength and weight is found for $S_{6}$ specimen where as $S_{2} \& S_{3}$ specimen gets exposed to greater acid resistance than control specimen $S_{1}$.

- The tensile strength of the concrete mix decreases as replacement of quarry and saw dust in sand increases.

- The strength of concrete depends on amount of replaceable materials i.e. QD and SD. Therefore, from the results the highest and lowest compressive strength is $S_{2} \& S_{6}$ specimens except control concrete.

- From the results on strength and durability studies clearly indicate that Quarry Dust and Saw dust can be used for a strong substitute for natural river sand with improved strength up to the substitute of $S_{3}$, therefore it saves concrete cost as well as reduce demand of sand.

\section{REFERENCES}

1) Hamid Mir, A., Improved Concrete Properties Using Quarry Dust as Replacement for Natural Sand. International Journal of Engineering Research and Development, Vol.11, Issue 03, PP.46-52, 2015.

2) Sumit L. Chauhan, Raju A. Bondre, Partial Replacement of Sand by Quarry Dust in Concrete, International Journal of Scientific and Research Publications, Vol.5, Issue 7, PP.1-4, 2015.

3) Yadav, H., Gurjar, P. S., Yadav, M., \& Ali, S., Use of Quarry Dust in Concrete as Replacement for Natural sand, International Research Journal of Engineering and Technology, Vol. 05 Issue: 09, pp. 1420-1422, 2018.

4) Balamurugan, G., \& Perumal, P., Use of Quarry Dust to Replace Sand in Concrete - An Experimental Study, International Journal of Scientific and Research Publications, Vol. 3, Issue 12, pp. 1-4, 2013.

5) Ganiron, T. U. J. (2014). Effect of Sawdust as Fine Aggregate in Concrete Mixture for Building Construction, International Journal of Advanced Science and Technology, Vol. 4 Issue 3, pp. 73- 82, 2014.

https://doi.org/10.14257/ijast.2014.63.07

6) Narayanan, A., Mary, A., Hemnath, G., \& Sampaul, K. (2017). Replacement of Fine Aggregate with Sawdust. International Journal of Advanced Research in Basic Engineering Sciences and Technology
(IJARBEST), Vol..3 Special Issue 35, pp. 206 - 210, 2017.

7) Osei, D. Y., \& Jackson, E. N. (2016). Compressive Strength of Concrete Using Sawdust as Aggregate. International Journal of Scientific \& Engineering Research, Vol. 7, Issue 4, pp. 1349-1353, 2016.

8) Akshay S., Arun S., Rushikesh R., Neeraj M., Ghadge M.D., Partial Replacement of Sand with Sawdust in Concrete, International Research Journal of Engineering and Technology, Vol. 05 Issue: 03, pp. 3098-3100, 2018.

9) Tilak, L. N., Kumar, S. M. B., Singh, M., \& Niranjan., Use of Saw Dust as Fine Aggregate in Concrete Mixture. International Research Journal of Engineering and Technology (IRJET), Vol. 5 Issue: 09 pp.1249-1253, 2018.

10)Tanveer Asif Zerdi, Md Yousuf, Mohammed Fariduddin, Mohammed Jaleel, Partial Replacement of Sand with Sawdust and Cow Dung in M15 Grade Concrete Production, Indian Journal of Research, Vol. 5, Issue: 5, pp. 163-164, 2016.

11) Mohd Fakri Muda, Saffuan Wan Ahmad, Fadhluhartini Muftah, Mohd Syahrul Hisyam Mohd Sani, Mechanical Behaviour of Mortar Made with Washed Bottom Ash as Sand Replacement, International Journal of Emerging Trends in Engineering Research, Vol. 7, No. 9,2019.

12)Harish Kumar, K., Sai Teja, T., \& Ramesh, B., Quality improvement on properties of concrete by using lightweight aggregates. International Journal of Recent Technology and Engineering, Vol. 8 Issue-2, pp. 4450-4454, 2019.

https://doi.org/10.35940/ijrte.B1858.078219

13)IS 383: 1970, Specification for coarse and fine aggregates from natural sources for concrete, Bureau of Indian Standard, New Delhi.

14) J. D. Chaitanya kumar, G.V.S. Abhilash, P. Khasim Khan, G. Manikanta sai, Experimental Studies on Glass Fiber Concrete, American Journal of Engineering Research (AJER), Vol. 5, Issue-5, pp-100-104, 2016.

15)IS 10262-2019, Concrete mix proportioningguidelines, Bureau of Indian Standards, pp. 1-40, New Delhi 2019.

16) Rama Krishna, B., Harish Kumar, K., Mani Kumar, T., \& Likitha, I., Properties of GGBS concrete under various curing conditions. International Journal of Emerging Trends in Engineering Research, Vol. 8 No. 2, pp. 1384-1387, 2020.

17)Muda, M. F., Ahmad, S. W., Muftah, F., Syahrul, M., \& Mohd, H., Mechanical Behavior of Mortar Made with Washed Bottom Ash as Sand Replacement, International Journal of Emerging Trends in Engineering Research, Vol. 7, No. 9, pp. 7-14, 2019.

18) Ankit J. Patel, Harsh N. Patel, Harsh R. Patel, Hardik R. Patel, Review on Use of Waste Material in Concrete, International Journal for Technological 
K. Harish Kumar et al., International Journal of Emerging Trends in Engineering Research, 8(5), May 2020, 1906 - 1915

Research in Engineering Volume 2, Issue 4, pp. 307-310, 2014.

19) Awasare V.G., Mahatme R.A., Patel A.A., Thorwat V.B., Patil P.V., Zambre A.B., An Experimental Study on Effect of Replacing Natural Sand by Artificial Sand on Properties of Concrete, International Research Journal of Engineering and Technology, Vol. 06 Issue: 03, pp. 6540-6546, 2019.

20)Bahoria B.V., Parbat D.K.and Naganaik P.B., Replacement of Natural Sand in Concrete by Waste Products: A State of Art, Journal of Environmental Research and Development, Vol. 7 No. 4A, pp. 6151-6154, 2013.

21)IS 456: 2000, Indian Standard, Plane and reinforced Concrete-Code of practice, Bureau of Indian Standard, New Delhi.

22)Meyyappan, P. L., \& Bharathbalji, G., Effect of Flyash in Enhancing the Strength and Durability Characteristics of Foam Concrete. International Journal of Recent Technology and Engineering, Vol. 8, Issue-4S2, pp.60-63, 2019. https://doi.org/10.35940/ijrte.D1015.1284S219

23) Nimitha. Vijayaraghavan, Dr. A.S. Wayal, Effect of Manufactured Sand on Durability Properties of Concrete, American Journal of Engineering Research, Vol. 02, Issue-12, pp-437-440, 2013. 